\title{
Rethinking the Federal Bias Toward Homeownership
}

\section{Citation}

Glaeser, Edward L. 2011. Rethinking the Federal Bias Toward Homeownership. Cityscape: A Journal of Policy Development and Research 13(2): 5-37.

\section{Published Version}

http://www.huduser.org/portal/periodicals/cityscpe/vol13num2/ch1.html

\section{Permanent link}

http://nrs.harvard.edu/urn-3:HUL.InstRepos:8052149

\section{Terms of Use}

This article was downloaded from Harvard University's DASH repository, and is made available under the terms and conditions applicable to Other Posted Material, as set forth at http:// nrs.harvard.edu/urn-3:HUL.InstRepos:dash.current.terms-of-use\#LAA

\section{Share Your Story}

The Harvard community has made this article openly available.

Please share how this access benefits you. Submit a story.

Accessibility 


\title{
Rethinking the Federal Bias Toward Homeownership
}

Edward L. Glaeser

Harvard University and the National Bureau of Economic Research

\begin{abstract}
The most fundamental fact about rental housing in the United States is that rental units are overwhelmingly in multifamily structures. This fact surely reflects the agency problems associated with renting single-family dwellings, and it should influence all discussions of rental housing policy. Policies that encourage homeowning are implicitly encouraging people to move away from higher density living; policies that discourage renting are implicitly discouraging multifamily buildings. Two major distortions shape the rental housing market, both of which are created by the public sector. Federal pro-homeownership policies, such as the home mortgage interest deduction, weaken the rental market and the cities where rental markets thrive. Local policies that discourage tall buildings likewise ensure that Americans have fewer rental options. The economic vitality of cities and the environmental consequences of large suburban homes with long commutes both support arguments for reducing these distortions.
\end{abstract}

\section{Introduction}

More than 85 percent of single-family dwellings are owner occupied; more than 85 percent of dwellings in homes with more than three units are rented. When the federal government subsidizes homeownership explicitly, through the home mortgage interest deduction, and implicitly, through the government-sponsored enterprises (GSEs) Fannie Mae and Freddie Mac, it is pushing Americans away from dense multiunit dwellings toward sprawling single-family detached homes. Local zoning rules that prohibit high-density and multiunit dwellings contribute to the governmental bias against compact development. Does it really make sense to stack the deck against energy-efficient, economically vibrant urban density?

Federal pro-homeownership interventions have long had three common justifications: (1) homeownership provides a path toward individual prosperity, (2) alleged market failures in the mortgage market require market-making federal action, and (3) homeownership establishes a connection with good citizenship. The great housing convulsion of the past decade challenges the first justification 
by reminding us that prices go down as well as up and that subsidized borrowing can lead to a "foreclosure" rather than an "ownership" society. Moreover, even if the secondary mortgage market needs public organizers to solve information-related market failures (a highly debatable proposition), those public organizers do not need to subsidize home borrowing as the GSEs have done. As the public is now beginning to see the bill for the GSEs' largesse, the national appetite for further subsidy of this nature seems to have diminished substantially.

Thus, the post-crash case for subsidizing ownership comes down to the connection between homeowners and citizenship. One can reasonably debate whether the correlations between ownership and citizenship-related variables such as voting in local elections are causal or large or valuable enough to subsidize (DiPasquale and Glaeser, 1999). ${ }^{1}$ One can even question whether subsidies that scale up with the size of a mortgage are either well designed or fair. In this article, however, I focus on a different reason to rethink federal housing policy and shift the focus from owning toward renting: ownership is tightly tied to structure type, and it is a mistake to subsidize people to live in large single-family houses instead of dense apartments.

Economists have often emphasized that the mortgage deduction would be nondistortionary if we effectively taxed the implicit housing services provided to themselves by homeowners. This argument is correct, and would have some weight if a tax on implicit housing services were politically plausible in the United States. But, in the absence of that tax, the mortgage deduction makes investing in homes far more attractive than investing in other, often more productive investments that yield financial returns (which are taxed) rather than housing services (which are not).

The connection between structure type and ownership is strong and understandable. In the Evidence on Homeownership, Structure, and Policies section of this article, I explore the simple logic of property rights and investment (for example, Grossman and Hart, 1986; Klein, Crawford, and Alchian, 1978). In general, ownership should be lodged with the agent who is in the best position to make investments and, in the case of a single-family detached house, that agent is the resident. In a multifamily dwelling, occupants share infrastructure and often lack any comparative advantage in investing in a roof or a boiler. Moreover, multiple owners make coordination costly, so renting, rather than owning, comes naturally to residents in bigger structures.

The implication of this connection between structure type and ownership is that subsidizing ownership is inherently subsidizing single-family detached dwellings, which means that these policies are implicitly encouraging moving away from high-density living. Because the home mortgage interest deduction subsidy scales up with the size of the mortgage, it also functions as a subsidy for larger homes, and, under some conditions, larger lots as well. It would be problematic to distort decisions about density and home size if, in the absence of interest rate subsidies, the free market was making socially optimal decisions.

Even without the subsidy, however, there would be too little density relative to the social optimum. Private decisionmakers ignore the pollution- and congestion-related externalities that are

\footnotetext{
${ }^{1}$ Green and White (1997) presented evidence suggesting that homeownership improves children's outcomes, which may present a more serious case for subsidizing homeownership. The correlation of omitted parental characteristics with homeownership, however, makes this connection difficult to tease out. Coulson and Li (2010) is an important paper that estimated homeownership spillovers.
} 
associated with larger homes away from the urban core. Larger homes use more energy and singlefamily detached homes, which are typically larger, use more energy than rental units. ${ }^{2}$ Local governments have consistently enacted rules that prevent dense development. From this perspective, federal pro-homeownership policies are distortions on top of other distortions and this fact implies that the social costs of these policies are likely to be even larger.

Although the positive externalities that could come from citizenship may suggest a case for subsidizing homeownership, the offsetting negative externalities will exist as long as the world fails to charge the social cost of carbon emissions and traffic congestion. Subsidizing homeownership is not just about subsidizing an asset class; it is also about subsidizing single-unit living, which tends to be away from the urban core. Encouraging people to flee cities to live in low-density homes hardly seems sensible. Although improving federal rental policy is certainly possible, perhaps by improving the portability of vouchers, the biggest way that the federal government affects the rental market is through its subsidy of homeownership, and it is surely time to rethink the size and extent of that subsidy.

Reducing the pro-homeownership bias would increase the demand for rental housing, and an unfortunate side effect of this increased demand might be that rental costs could increase. One way to mitigate a rental cost increase would be to reduce the barriers to multiunit building that exist in much of the United States. Although these barriers are enacted at the local level, they affect the nature of America's built environment and even the distribution of population across the United States as a whole. In many metropolitan areas, suburban enclaves have made it extremely difficult to build the kind of dense developments that would typically be rented. For example, a large share of suburban Boston is completely off limits to multifamily dwellings (Glaeser, Schuetz, and Ward, 2006). In cities, significant barriers to building have also existed, including in large historic preservation districts. These barriers make housing more expensive, and, when they prevent large multiunit structures, they limit America's stock of rental housing.

In the penultimate section of this article, I discuss these barriers and what can potentially be done to encourage localities to internalize the social costs of barriers to building up. Because the federal government cannot directly control local land use rules, the most practical approach would be to create financial incentives for more permissive construction of multifamily units. One approach would be to use funds taken from either a decreased home mortgage interest deduction or from the problematic low-income housing tax credit (LIHTC) to sponsor a density fund, based loosely on the U.S. Department of Education's "Race to the Top" fund, that would reward a few localities with unrestricted aid in exchange for their meaningfully reforming local land use controls in a way that creates more high-density rental units.

In the next five sections, I (1) revisit three nonstructure-related reasons to question the home mortgage interest deduction; (2) focus on the link between ownership and structure type; (3) present facts about ownership, structure type, and energy usage; (4) provide a brief discussion of landuse-related issues; and (5) conclude with a modest policy proposal that involves reforming the home mortgage interest deduction and creating a fund to prod localities toward constructing highdensity, presumably rental, dwellings.

\footnotetext{
${ }^{2}$ http://www.eia.doe.gov/emeu/recs/recs2005/c\&e/spaceheating/pdf/allTablesl-13.pdf.
} 


\section{Three Nonstructure-Related Reasons To Rethink the Mortgage Deduction}

Before addressing the connection between ownership and structure type, I will first restate the three primary objections to the home mortgage interest deduction in its current form. ${ }^{3}$ (1) Although support for homeownership is often billed as providing a path toward wealth accumulation, the deduction is just as likely to encourage excessive risk-taking; (2) as Poterba and Sinai (2008) documented, the deduction is extremely regressive; and (3) the deduction distorts the purchase decision and encourages excessively large housing units.

\section{Does the Interest Deduction Lead to Wealth Accumulation?}

One core rationale often given for subsidizing ownership is that homeownership can be a path toward asset accumulation. Although one can ask why homes, of all forms of assets, should be so privileged, it is reasonable to revisit the question of whether the home mortgage interest deduction increases asset accumulation at all.

I start by assuming that the government has some interest in promoting wealth accumulation, perhaps because wealthier individuals are less likely to burden people around them or because the tax code reduces other forms of investment by taxing capital gains and dividends. If this is the primary motivation for encouraging asset accumulation, then it seems likely that the social value function is quite concave in private wealth because the goal is primarily avoiding extreme hardship. This challenges any strategy that leads toward excessive private risk-taking, such as encouraging people to borrow money with which to bet on a risky asset such as housing.

The best case for homeownership as asset accumulation is that (1) the individual saves more ex ante to get a down payment; (2) the person then buys a home, and the value of the home increases as home prices rise; and (3) the homeowner then pays down his or her mortgage. If all three events occur in this fashion, then homeownership will increase asset accumulation. Certainly, homes have typically been the largest asset for many American households.

Yet some of these events might not occur and might even be reversed because of home mortgage policies. The volatility of the housing market over the past 4 years has clearly illustrated that housing prices go down as well as up. In general, the Americans who bought houses during the boom have lost money and are now in far worse financial shape than if they had not bought. The asset accumulation approach will only operate effectively if we are confident that homes are likely to increase in value over time. In large parts of America, we have no reason to expect prices to rise regularly, and, in some cases, encouraging homeownership is a recipe for increased wealth loss.

As with any other properly functioning industry, the construction industry experiences technological improvements and increased efficiency. In the computer industry, technological progress has

\footnotetext{
${ }^{3}$ By current form, I mean without an accompanying tax on implicit housing services. If housing services were taxed, then the tax deduction would eliminate a bias favoring self-financing versus borrowing and could be quite justified. I do not believe that either a housing service tax or a consumption tax is on the table, so I will constrain my discussion to a comparison of deduction or not, holding everything else constant. Also notably, the discussion is pertinent primarily for the Americans for whom the deduction actually materially lowers their housing costs.
} 
led to affordable laptops with computing power that would have been exorbitantly expensive in 1980. As a result, no one buys a computer assuming that it will rise in value. The real cost of building a home declined by about 3 percent in both the 1980s and the 1990s (Glaeser, Gyourko, and Saks, 2005). In principle, declining construction costs could also lead to homes becoming more affordable year after year.

Declining construction costs have not always led to declining home prices, because homes have two other crucial ingredients: land and permits. When those two ingredients are not scarce-and they are not in much of America—then construction prices dominate, and we should expect prices to stay flat or fall. Indeed, in many major metropolitan areas, real housing prices barely rose between 1980 and 2000. Even Census self-reported home values, which do not adjust for generally increasing housing quality, suggest that prices stayed flat between 1980 and 2000 for many of America's fastest growing cities, such as Las Vegas and Miami. In Houston, which is expanding, prices dropped dramatically. The core economics of housing prices suggests that this price stagnation is perfectly normal, because America has abundant land and because we expect the construction industry to become more efficient over time.

Nonetheless, even if housing prices decline over time, people will still accumulate wealth through homeownership if they pay down their mortgage. This savings channel has operated for millions of American households throughout history, but mortgage innovation and the subsidization of home mortgages can actually reduce this savings channel. Subsidizing homeownership will lead to savings if people are not regularly drawing value out of their homes with second mortgages. The home mortgage interest deduction, however, creates an incentive for people to draw more wealth out of their home by subsidizing the interest rate at which they will borrow. At the extreme, the interest deduction encourages people to have the maximum possible loan-to-value ratio, which ensures that they will have little wealth accumulation and great risk regarding changes in home values.

A similar effect is at work when we look at the fact that needing a down payment can affect wealth accumulation. A pure homeownership incentive will encourage people to save to ensure that they have the down payment needed to borrow. Subsidizing leverage and working to lower down payment requirements can work in the opposite direction. Subsidizing borrowing encourages lenders and borrowers to work together to ensure that the borrower needs as small of a down payment as possible. This subsidy reduces the incentive to save. Altogether, it is hard to see the home mortgage interest deduction as a sensible way to encourage Americans to accumulate wealth.

\section{Progressivity and the Deduction}

A second obvious problem with the home mortgage interest deduction is that its benefits go disproportionately to the wealthiest Americans. Poterba and Sinai (2008) estimate that the home mortgage interest deduction typically saves $\$ 523$ per year in taxes for homeowning families earning between $\$ 40,000$ and $\$ 75,000$. The average annual tax savings for families earning more than $\$ 250,000$ dollars is $\$ 5,459$. This calculation treats current mortgage levels as fixed, and, if the deduction were eliminated, some people would pay down their mortgages and prices would also change. Nonetheless, the 10-fold gap in savings illustrates the extent to which the deduction's benefits flow to more prosperous individuals. 
Many people may object to the regressive nature of the deduction on social equity grounds, but that is more a matter for philosophers and politicians than for economists. From a purely economic perspective, the regressive nature of the tax deduction may be problematic because it suggests that the deduction is poorly targeted. From a narrow economic perspective, the fact that the benefit goes disproportionately toward more prosperous individuals raises doubts about whether it effectively encourages homeownership.

Jesse Shapiro and I used the 1998 Survey of Consumer Finance to examine homeownership and deductibility by income group (Glaeser and Shapiro, 2003). We found that more than 90 percent of households in the top quintile of the income distribution are homeowners. This group appears to be at a corner solution in which essentially all rich people own houses. This finding surely reflects a strong connection between income and wanting to live in a single-family detached house (Glaeser, Kahn, and Rappaport, 2008). The model in the appendix also suggests that homeownership should yield higher benefits in high-quality units that require a lot of regular maintenance. Similarly, richer people may choose to modify their homes, which is easier to do in an owneroccupied house. In the model, the ease of modification in an owner-occupied home would come from the fact that any such investments in a rental unit would then lead to higher rent charges from the landlord.

Although it seems likely that most wealthy people would own houses with or without the tax deduction, poorer Americans are much more likely to be split between owning and renting. For example, people in the third, fourth, and fifth income deciles are almost evenly split between owning and renting. The Poterba and Sinai (2008) evidence, however, suggests that this group is benefiting far less from the deduction. Moreover, Glaeser and Shapiro (2003) found that these middle-income homeowners often do not even itemize when they file their annual income tax returns. As such, the deduction yields substantial benefits to people who are likely to own anyway and does much less for the middle-income group that seems more likely to be in the margin between owning and renting.

Glaeser and Shapiro (2003) also marshaled evidence suggesting that changes in the value of the deduction have only modest effects on homeownership levels. For example, as Poterba (1984) demonstrated, the value of the deduction is sharply tied to the inflation level, because nominal interest rate payments rise with inflation. Little evidence suggests, however, that homeownership rose substantially during periods when the deduction was more valuable. Glaeser and Shapiro also examined the effect of state-level heterogeneity in the value of the mortgage interest deduction and again found essentially no link between the size of the deduction and homeownership. This finding may reflect that the deduction is poorly targeted at increasing homeownership.

These criticisms are less telling toward the implicit mortgage subsidies that the GSEs created. The canard that suggested that these entities improved mortgage markets without subsidy has been proven false by the markets' collapse and subsequent bailout, and, as such, they can be seen as providing —in part—a second mortgage subsidy to homebuyers. This subsidy, however, is more effectively targeted toward middle-income Americans. Of course, other significant problems exist with the GSE model, which creates a private for-profit entity that can borrow at extremely low rates because of an implicit government guarantee. 
Moreover, the GSE interest-rate subsidy, like the home mortgage interest deduction, also encourages Americans to borrow heavily to bet on the vicissitudes of the housing market. Before the housing crash in 2008, many believed that encouraging people to borrow money to buy housing was an attractive way to create an "ownership society" in which more Americans accumulated assets. After the crash, this homeownership incentive seems just as likely to have created a "foreclosure society," filled with people who were encouraged to bet everything on the unlikely event that housing prices would only go up.

\section{The Deduction and Home Size}

The home mortgage interest deduction also creates a subsidy that encourages people to buy bigger homes. Because the amount that can be deducted scales up with the size of the mortgage, and because the size of the mortgage is related to the size of the home, people have an incentive to buy bigger homes if they want to receive a larger deduction.

In the first half of the 20th century, it was possible to believe that Americans should be consuming more housing. In 1940, 35 percent of American homes lacked a sewage or septic connection, 20 percent had more than one person per room, and 9 percent had more than 1.5 people per room (Glaeser and Gyourko, 2008). In those years, legitimate public health concerns prompted an interest in larger, better quality homes. Moreover, in the wake of the Great Depression, it was certainly reasonable to consider in-kind and cash-based redistribution, and federal support of housing could be justified on those grounds as well.

By 2010, however, the case for encouraging Americans to own bigger houses had essentially disappeared and, today, a better case is to be made for discouraging living large. By 1990, only 1.1 percent of homes lacked a sewage or septic connection and, 10 years later, the Census stopped asking the question because decent sewage was so universal. In 2000, only 5.7 percent of American homes had more than one person per room. On average, each American has more than two rooms and 992 square feet of living space (Glaeser and Gyourko, 2008). This number is astonishingly large by both historical and world standards. Average living space per capita is less than 450 square feet in Great Britain, France, and Germany. America is an extraordinarily well-housed nation.

Even more astonishingly, poor Americans are, on average, living in very big homes. In the bottom quintile of the American income distribution, the average person has 855 square feet of living space, more than twice the overall average consumption in France and the United Kingdom (Glaeser and Gyourko, 2008). In fact, among homeowners, the connection between square footage and income is extremely weak, in part because poorer Americans often live in places where housing is extremely cheap.

Although little reason exists to encourage Americans to buy bigger homes, increasingly legitimate reasons encourage thinking that externalities are associated with more housing consumption. Perhaps the most obvious externality is associated with home energy consumption. Bigger homes typically use more electricity and home heating. According to the Residential Energy Consumption Survey homes with between 2,500 and 3,000 square feet of heated living space use 41 percent more kilowatt hours of electricity, 8 percent more natural gas, and 19 percent more fuel oil than 
homes with between 1,500 and 2,000 square feet of heated space. ${ }^{4}$ Greater energy use in larger homes leads to more carbon emissions, and, if those carbon emissions create a negative global externality associated with climate change, then the government should be pushing for smaller rather than larger homes.

Negative externalities are also associated with bigger homes if those homes occupy larger lots. A larger amount of ground space per capita implies more travel. Because this distortion is also linked to structure type, I revisit this issue in the section on homeownership, structure, and policies.

\section{The Economic Logic of Ownership and Structure Type}

The regressivity of the home mortgage interest deduction, or its effect on structure size, would occur even if everyone lived in a single-family detached home or if everyone lived in a multifamily dwelling. Because of the strong connection between homeownership and structure type, however, subsidizing homeownership implicitly subsidizes single-family dwellings. Although many condominium owners do take advantage of the deduction, a natural connection exists between ownership and structure type, and that means that subsidizing homeownership affects the physical structure of America. If all owners lived in single-family detached homes and all renters lived in multifamily dwellings, then subsidizing homeownership would be exactly the same as subsidizing single-family detached dwellings. Reality is not far from that extreme. In this section, I discuss the theory behind the structure-ownership connection.

I have already argued that the home mortgage interest deduction may not play that much of a role in encouraging homeownership; in that case, it may not play that much of a role in encouraging structural change either. Nonetheless, the deduction serves as a catalyst for homeownership and other federal policies, such as the implicit subsidies for Freddie Mac and Fannie Mae, which encourage people to own rather than rent. This section examines the effect that any such push for homeownership is likely to have on structure type.

Ultimately, homeownership is simply about the decision to assign property rights over an asset to one person or another. Therefore, making sense of homeownership requires investigating the core insights of research on property rights that have blossomed in recent decades (for example, Grossman and Hart, 1986). One hallmark of this literature is that the assignment of ownership can serve to mitigate the social losses associated with different contracting problems. For example, Klein, Crawford, and Alchian (1978) argued that the General Motors Corporation (G.M.) bought Fisher Body to minimize hold-up problems associated with relationship-specific investments. G.M. needed Fisher Body to invest in very specific products to meet its needs as a downstream customer, but once Fisher Body made those investments, G.M. could hold up Fisher Body and threaten to pay less. Klein (2006) shows that the difficulties of this relationship were solved only when G.M. bought Fisher Body.

That same intuition helps us understand homeownership. Two critical forms of investment relate to the homeownership decision. The first, emphasized by Henderson and Ioannides (1989), relates

\footnotetext{
${ }^{4}$ http://www.eia.doe.gov/emeu/recs/recs2005/c\&e/spaceheating/pdf/allTablesl-13.pdf.
} 
to structure-specific maintenance or excessive use. Homes require a fair amount of care and they suffer when abused. Tenants have only a limited incentive to invest in their homes, and, as has been empirically well documented, rental homes depreciate more swiftly than owner-occupied housing (Shilling, Sirmans, and Dombrow, 1991). As Henderson and Ioannides (1989) wrote, assigning ownership to the occupier provides more incentives for taking better care of the housing units.

The model in the appendix explores this intuition. At its heart, the model follows Grossman and Hart (1986) and examines the connection between ownership-structure and some noncontractible investment, such as cleaning the gutters in a house or fighting mold. If the unit is owner occupied, the owner undertakes such investments; if the unit is rented, either the landlord or the tenant undertakes the investments.

Owners are more likely than renters to undertake maintenance operations for two major reasons. First, the owner captures the long-term price effects of the maintenance, which the renter does not. Second, the renter will actually suffer if better maintenance leads the landlord to raise rents. Both forces suggest that owner-occupiers will take better care of homes than renters.

It is less obvious, however, that owner-occupiers will take worse care of their homes than landlords. After all, the landlords have the same long-run price incentives and they benefit from the higher rent that they can charge as a result of maintenance.

The model in the appendix emphasizes two reasons why owner-occupiers may do more than landlords to invest in apartments and two reasons why landlords may invest more than owneroccupiers. One reason compelling landlords to invest less is that long-term rent contracts at a fixed rate reduce the connection between maintenance and rent and dilute the landlords' incentive to invest. Frankena (1975) made this point in the rent control literature. Even if the rent is flexible, if it is decided by ex post bargaining, the landlords will under-invest unless they have complete bargaining power.

A second force leading landlords to invest less money in their properties is that owners may use their own time to maintain the home, while landlords often hire outside help and must pay taxes on the wages earned by that help. Assume that an investment of 50 person-hours will increase the resale value of the unit by $\$ 1,000$ dollars (ignoring discounting). Assume further that the market wage of both the owner-occupier and a maintenance worker hired to care for the unit equals $\$ 25$ per hour and that the tax rate is 30 percent, so that the average tax wage rate is $\$ 17.50$. The owner-occupier gains $\$ 1,000$ in extra housing value (the capital gains of the home are untaxed) at a cost of $\$ 875$. The landlord gains the same $\$ 1,000$ in housing value but must pay $\$ 1,250$. As a result of this price discrepancy, the owner-occupier is more likely to engage in the improvement. In fact, it is quite possible that the owner-occupier will engage in too much maintenance, at least relative to working outside the home, because wages are taxed but the benefits from home maintenance are not. Of course, if externalities from home maintenance exist, then private maintenance will be too low without the tax wedge advantage.

An added advantage from owner-occupier maintenance is that the owner-occupier lives in the home, which means the person providing the maintenance has more information about the state of the home and fewer travel costs. Some of the advantages of owner-occupancy versus absent landlord vanish when the landlord also lives in the building and provides maintenance personally. 
This situation is not unusual in lower density dwellings, such as Boston's triple decker (three-story) apartment buildings, where the owner often lives in the home and does not need to travel. A tax wedge still exists, however, because the higher rents that come from landlord maintenance get taxed, while the quality-of-life benefits that the owner-occupier receives from maintenance do not.

Other factors challenge the tenant's advantage in providing maintenance and lead to landlord maintenance. The landlord may either have or be able to hire specialized human capital in home maintenance. If external maintenance providers are significantly more efficient than the owner-occupier is, then hiring such providers may eat into the tax wedge advantage of personal maintenance. If external provision is much better, then the owner-occupier may hire external help as well, which eliminates the tax wedge altogether. As long as the owner-occupier can hire the same outside talent at the same wage that the landlord pays, this scenario will not lead to less maintenance by the owner-occupier. If the landlord has more knowledge of the outside market for maintenance talent or if there are returns to scale in hiring such talent, then the landlord may indeed have a maintenance edge. A second force that may induce more maintenance among landlords is regulations that may require a certain level of maintenance.

As Henderson and Ioannides (1989) argued, maintenance-related benefits help explain homeownership levels and in what situations to expect more homeownership. The model in the appendix unsurprisingly predicts that higher tax levels will lead to more homeownership, because the value of the tax wedge is higher and because people who are particularly unskilled at home maintenance, relative to landlords, will be more likely to rent. Assuming that landlords do provide less maintenance because rents do not adjust closely to investments, then more ownership of structures will occur in situations in which maintenance is more valuable.

The model also considers multifamily units, in which only two types of maintenance exist. Some maintenance investments are specific to the unit, but others are specific to the building, such as maintaining the roof or the boiler. The basic logic of such interventions is similar to the algebra already discussed, except insofar as the maintenance action creates externalities to neighbors either because the actual maintenance creates negative externalities while it is going on, or because unitspecific maintenance makes the block of units more attractive as a whole. Although it is possible for individual owner-occupiers in a multifamily building to undertake such actions on their own, it is more natural for them to coordinate in some fashion with a condominium or cooperative association.

Once an association makes a maintenance decision, however, a great deal can go wrong. Coordination costs, especially those involving the time of owners, may be substantial. Delegating out management can be very expensive as well. The model assumes that these coordination costs scale up with the size of the building.

That assumption leads to the prediction that owner-occupancy will be more common for smaller structures than for bigger structures. For smaller structures, the tax wedge and the fact that owneroccupiers internalize all the benefits from maintenance dominate and encourage ownership. For larger structures, the costs of coordinating activities dominate and as a result, it is more efficient to have a single landlord, even one who is under-investing in maintenance. This logic suggests that ownership should be less common in bigger buildings. 
Finally, the model turns to social capital investments, which are defined as investments that affect the quality of the neighborhood but not the structure. These investments require time but not money and only the residents themselves can make them. These investments may also create externalities. In general, we should expect to see more investments from homeowners than from renters, both because homeowners internalize the benefits of future price increases and they do not lose from increases in rents. This tendency for homeowners to make social capital investments provides one justification for the correlations between homeownership and social capital, as found by DiPasquale and Glaeser (1999) and others.

This connection is particularly relevant if investments in social capital create positive externalities. In that case, this connection becomes the primary justification of national pro-homeownership policies. I now assume that the social benefits from these investments are proportional to the private benefits and ask what conditions might increase the size of the homeownership externality.

One particular question is whether structure type or individual characteristics will connect with these investments. For example, it is natural to assume that both the benefits and costs of investment are a function of the size of the building. It might be easier to connect with others in large dense structures. Alternatively, the benefits of social capital might be lower or higher in denser areas. Social capital might be less valuable if people are more connected to the streets in shorter buildings or it might be more valuable if the community associations are needed to make blocks safer.

The model shows that the relationship between building size and the cost of developing social capital is critical in determining whether the effect of homeownership on social capital increases with building size. If bigger buildings reduce the cost of interactions, then the social capital-related benefits of ownership, and any externality from that social capital, will actually be larger in owneroccupied buildings.

Another way in which individual characteristics or structure type might affect the decision to subsidize social capital by subsidizing homeownership is to influence the size of the externality relative to private benefits. Any variable that increases the size of the external benefits from these investments without affecting the private decision to invest will naturally make public subsidy more appealing. The question then becomes empirical: What do we know about the differential effect of homeownership on forms of social capital investment and what do we know about the size of the externalities?

The model appendix also suggests that the link between social capital and homeownership can be reversed if large, dense dwellings act to lower the costs of social interactions sufficiently. If people who live near one another in dense neighborhoods find it much easier to interact than do people who are spread out at long distances, then the subsidization of homeownership can perversely lower social capital, even though homeownership—holding structure constant-increases investment in social capital. We will discuss the evidence on this possibility in the next section. 


\section{Evidence on Homeownership, Structure, and Policies}

In this more empirical section, I explore five different topics and discuss the policy issues that surround them. The first subsection recalls the basic facts about homeownership and structure type. The second subsection looks at the connections among structure type, ownership, cities, and density. Subsidizing homeownership does seem to mean subsidizing suburbia. The third section focuses on the pollution and congestion externalities associated with subsidizing ownership and single-family detached homes. The fourth section focuses on the economic effect of subsidizing people to live in metropolitan areas where single-family detached homes are more common. The fifth section returns to the social consequences of these policies.

\section{Homeownership and Structure Type}

Exhibit 1 shows the breakdown of ownership by structure type using the 1970 and 2000 Census Individual Public Use Microsample. The results are as follows: first column, the entire population in 2000; second column, the top quintile of the population by income in 2000; third column, the lower quintile of the population by income in 2000; and fourth column, 1970. I have excluded mobile homes and other nonpermanent structures.

The first row gives results for single-family detached housing. In the United States as a whole in 2000, 86.8 percent of these units were owner-occupied and 13.2 percent were rented in 2000. Among the richest quintile of Americans, the ownership rate in this structure type was an astonishing

\section{Exhibit 1}

Ownership of Housing Units by Structure Type, 1970 and 2000

\begin{tabular}{|c|c|c|c|c|c|}
\hline Structure Type & $\begin{array}{l}\text { Ownership } \\
\text { Status }\end{array}$ & $\begin{array}{c}\text { (1) } \\
\text { Entire } \\
\text { Population, } \\
2000 \\
(\%)\end{array}$ & $\begin{array}{c}\text { (2) } \\
\text { Top Quintile } \\
\text { by Income, } \\
2000 \\
(\%)\end{array}$ & $\begin{array}{c}\text { (3) } \\
\text { Bottom Quintile } \\
\text { by Income, } \\
2000 \\
(\%)\end{array}$ & $\begin{array}{c}\text { (4) } \\
\text { Entire } \\
\text { Population, } \\
1970 \\
(\%)\end{array}$ \\
\hline \multirow[t]{2}{*}{ 1-family house, detached } & Owned & 86.77 & 95.64 & 73.35 & 81.64 \\
\hline & Rented & 13.23 & 4.36 & 26.65 & 18.36 \\
\hline \multirow[t]{2}{*}{ 1-family house, attached } & Owned & 65.04 & 84.09 & 45.72 & 58.45 \\
\hline & Rented & 34.96 & 15.91 & 54.28 & 41.55 \\
\hline \multirow[t]{2}{*}{ 2-family building } & Owned & 26.04 & 53.82 & 15.08 & 33.71 \\
\hline & Rented & 73.96 & 46.18 & 84.92 & 66.29 \\
\hline \multirow[t]{2}{*}{ 3- to 4-family building } & Owned & 13.69 & 36.34 & 6.99 & 14.12 \\
\hline & Rented & 86.31 & 63.66 & 93.01 & 85.88 \\
\hline \multirow[t]{2}{*}{ 5- to 9-family building } & Owned & 10.04 & 28.05 & 4.66 & 6.02 \\
\hline & Rented & 89.96 & 71.95 & 95.34 & 93.98 \\
\hline \multirow[t]{2}{*}{ 10- to 19 -family building } & Owned & 9.10 & 24.88 & 4.84 & 3.90 \\
\hline & Rented & 90.90 & 75.12 & 95.16 & 96.10 \\
\hline \multirow[t]{2}{*}{20 - to 49 -family building } & Owned & 11.63 & 34.24 & 5.91 & 3.93 \\
\hline & Rented & 88.37 & 65.76 & 94.09 & 96.07 \\
\hline \multirow[t]{2}{*}{ 50-family or larger building } & Owned & 13.17 & 37.46 & 5.43 & 6.51 \\
\hline & Rented & 86.83 & 62.54 & 94.57 & 93.49 \\
\hline
\end{tabular}

Source: Ruggles, Steven, J. Trent Alexander, Katie Genadek, Ronald Goeken, Matthew B. Schroeder, and Matthew Sobek. 2010. Integrated Public Use Microdata Series: Version 5.0 [Machine-readable database]. Minneapolis: University of Minnesota 
95.6 percent. Even among the poorest quintile, the ownership rate was 73.3 percent. In 1970, the ownership rate for single-family detached houses was 81.6 percent. The rental of a single-family detached unit is relatively rare and concentrated among poorer Americans.

Single-family attached homes are significantly more likely to be rented. In this group, the total homeownership rate falls to 65 percent. The homeownership rate is 84 percent among the richest quintile but only 46 percent among the poorest quintile. In 1970, the ownership rate for attached single-family homes was 58 percent. This is clearly a middle category in which ownership and renting both are attractive. Two-family homes occupy the same place, resulting in a substantial mixture between owner-occupied and rental units, and renting is, as always, higher among poorer Americans.

When we consider three- or four-family units, however, the rental rate skyrockets. In the United States as a whole, the ownership rate in three- or four-unit structures is only 13.7 percent. This figure has changed little since 1970, when the rate was 14.1 percent. Even among the richest quintile of Americans, only 36 percent own if they live in three- or four-unit structures.

Among even larger structures, the ownership rate is typically even lower. In structures with 5 to 50 units, the rental rate is more than 88 percent. This figure is lower than it was in 1970, which perhaps reflects the fact that the home mortgage interest deduction provides a large incentive to own expensive condominiums.

The tight connection between structure type and ownership also holds across places. Exhibit 2 shows the -. 68 correlation between the share of households that are single-family detached and the share of households that are owner occupied. The large differences in structure type across

\section{Exhibit 2}

Correlation Between Share of Owner-Occupied and Single-Family Detached Housing Units, by MSA

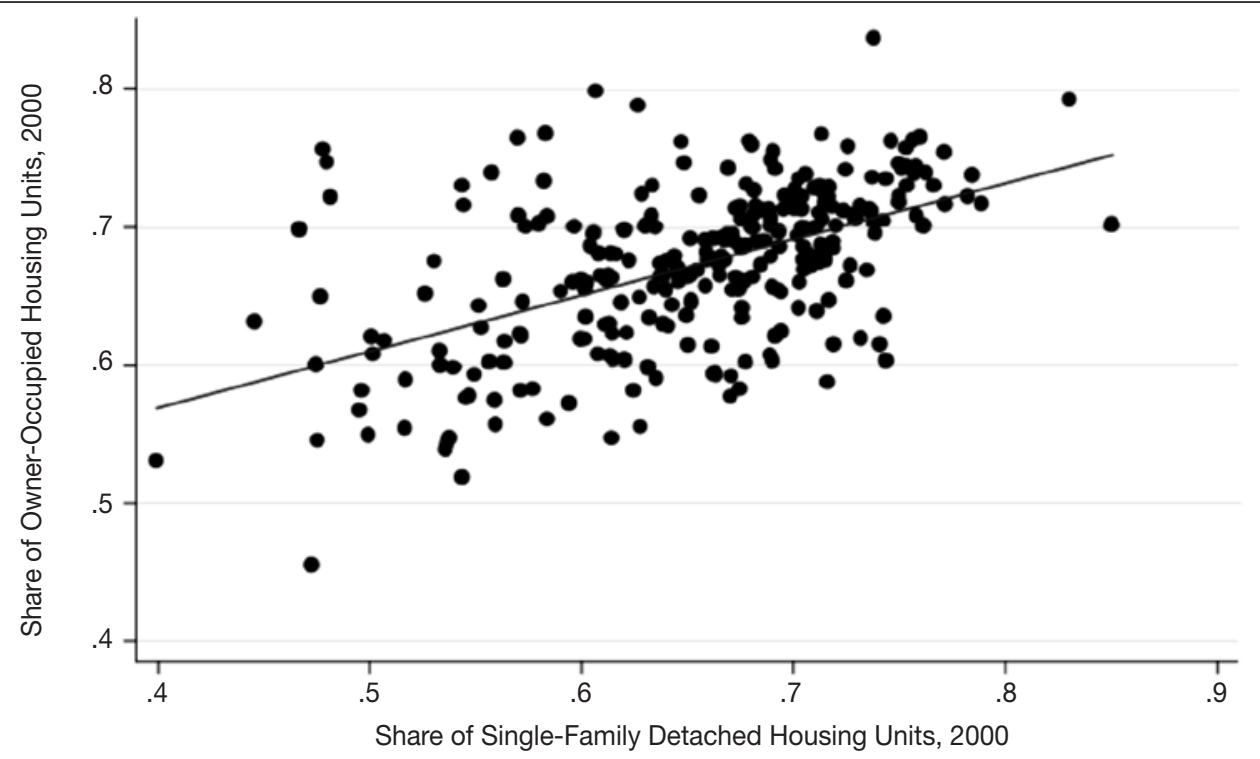

$\overline{M S A}=$ metropolitan statistical area. 
metropolitan areas suggest that subsidizing single-family detached dwellings not only encourages people to live in single-family dwellings within metropolitan areas, but it also encourages people to live in metropolitan areas that are more oriented toward single-family detached dwellings.

Does the connection between homeownership and structure type reflect the maintenance- and investment-related issues discussed in the previous section? Previous work has already shown that rental units depreciate more quickly than owner-occupied units (Shilling, Sirmans, and Dombrow, 1991). Exhibit 3 reminds us of the difference in quality levels between owner-occupied and rental units. Using the American Housing Survey, I separated properties into four groups, by ownership type and structure type. Our two structure type classifications are single-family detached structures and structures with five or more units.

Across many types of problems, rental units had significantly more examples of maintenance problems. For example, almost 2.5 percent of renter-occupied units had open cracks or holes, but the share of owner-occupied units with these problems was less than 1.3 percent. Nearly 3.5 percent of renter-occupied heads of household described their housing as "moderately inadequate" or "severely inadequate," but only 1 percent of owner-occupied heads of household described their housing this way.

These differences also hold within structure types. For example, 2.8 percent of renter-occupied single-family detached dwellings had open cracks or holes, as opposed to 1.2 percent of owneroccupied single-family detached dwellings. More than 2 percent of renter-occupied multiunit dwellings had this problem, compared with less than 1 percent of owner-occupied multiunit dwellings. In rented single-family homes and multifamily homes, 1.25 and 1.04 percent, respectively, reported broken plaster and peeling paint, but in owner-occupied homes the corresponding numbers were 0.49 and 0.35 percent.

For the data in the second to last column, I tested whether the gap in problems between owneroccupied and rental units is statistically larger for single-family detached dwellings than for multiunit dwellings. I reported the t-statistic for the interaction between owner-occupied units and singlefamily detached structures. In some cases, I found that this is the case. For example, the reduction in large, open cracks that is associated with owner-occupied housing is larger in single-family detached units.

Some of this difference may reflect differences in the demographics of the residents. In the last column, I show the t-statistic on the interaction between structure type and ownership when I have also controlled household income, education, race, and age. In this case, I found somewhat different results that are still generally compatible with the view that ownership reduces maintenance problems more in single-family detached dwellings.

One interpretation of these mixed results is that, although renting multifamily dwellings still leads to fewer maintenance problems, it also leads to less time and effort spent in coordinating responses to those problems, as the model suggests. Because I am unable to measure these costs, this statement must remain speculation.

Overall, however, the connection between structure type and ownership type is clear. Moreover, some evidence suggests that this link is related to a core advantage that ownership provides in 


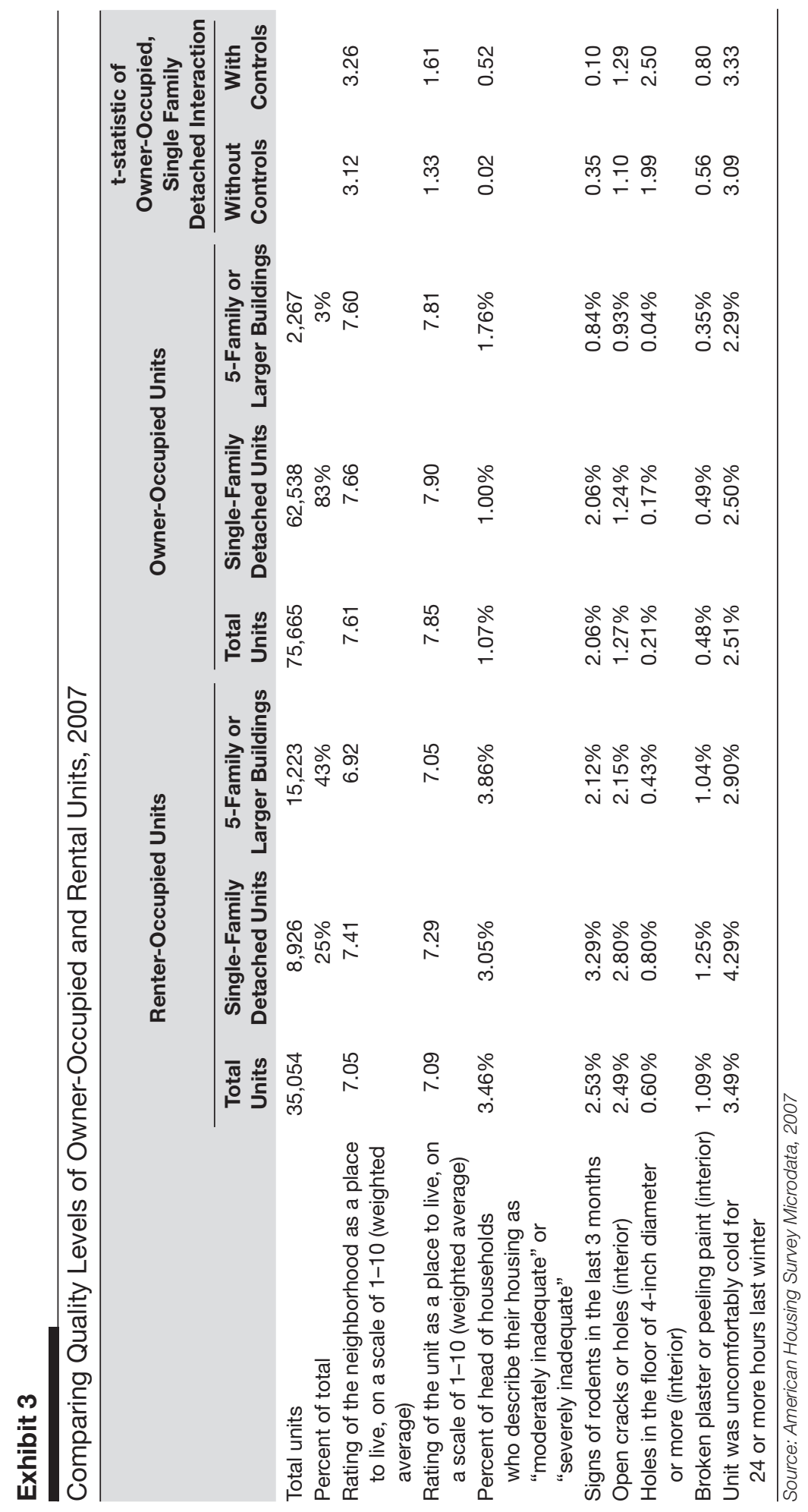


addressing the incentive problems involved in maintaining single-family detached houses. The implication of this advantage for policy is that subsidizing ownership implicitly means subsidizing single-family detached housing.

\section{Structure Type, Ownership, Cities, and Density}

Because of the link between homeownership and structure type, one consequence of the home mortgage interest deduction, which would result from any pro-homeownership policy, is that people move away from rental housing, which is far more likely to be in larger buildings that are closer to city centers. The link between structure type and ownership also explains why renting is more likely in urban cores and ownership is more likely outside of those areas. High land values in urban centers make it more attractive to build upwards, which, in turn, makes renting more attractive.

The link between residence in central cities and renting is fairly universal. According to the 20062008 American Community Survey, 76 percent of Manhattan residents rent but 64 percent of the residents in suburban Westchester County own their own homes. In Boston, 62 percent of residents rent, but 65 percent of residents in suburban Middlesex County own. In Chicago, 51 percent of residents rent, but 62 percent of the residents in Cook County own. This pattern is weaker but still present in the newer areas of the Sunbelt: in Los Angeles 61 percent of city residents rent, but 62 percent in Orange County own. In Atlanta, 49 percent of city residents rent, but 59 percent of Clinton County residents own. The connection between central city location and homeownership is sufficiently strong that encouraging homeownership is implicitly encouraging deurbanization.

Across metropolitan areas, little correlation exists between density and owning among the least dense areas. In these places, ownership is enormously common and little variation is evident in the share of single-family detached dwellings, which tends to be quite high. Among the dense 50 percent of metropolitan areas, the correlation among area density, renting, and share of the population that lives in single-family detached dwellings is much stronger. In this most dense 50 percent of metropolitan areas, the correlation between the logarithm of population density in 2000 and the share of units that are rented is 38 percent and the correlation between that density measure and the share of units that are single-family detached is 55 percent.

These correlations and the significant variation in areas across space suggest that subsidizing homeownership is implicitly subsidizing people to move away from city centers and to move toward lower density metropolitan areas. These effects are likely to increase pollution and congestion, at least within areas, and to lead people to live in less economically productive areas. I explore those effects next.

\section{Structure Type, Ownership, Energy Use, and Congestion}

One reason to be concerned about a large federal program that encourages people to live in singlefamily detached houses is that such houses are typically farther away from urban centers. The distance from the city center is associated with more driving, which can create externalities both through emissions and through traffic. For example, using the National Household Travel Survey, Glaeser and Kahn (2010) found that, when a household's distance to the central business district doubles, the household's annual gasoline usage increases by 44 gallons, even holding household 
income and neighborhood density constant. A strong empirical link also exists between the density of an area and per-household fuel consumption (Glaeser and Kahn, 2010). Using the National Household Travel Survey, I estimated that, as density levels drop by 50 percent, households use an average of 81 additional gallons per year, holding household income and distance to the city center constant. Encouraging an urban exodus increases carbon emissions.

The same logic holds true across metropolitan areas. Glaeser and Kahn (2010) found that gasoline usage increased with metropolitan decentralization and decreased with metropolitan population density. By encouraging people to move to less centralized, less dense areas, promoting homeownership increases driving and energy use.

Exhibit 4 shows results on commuting by car, structure type, and homeownership using the 2000 Census. The table reports regressions, in which I control for individual income and age. I found that homeowners are 11 percent more likely to commute by car than are renters. In the second regression, I documented the strong connection between structure type and car commuting. The third regression shows that more than one-half of the connection between homeownership and car commuting reflects the connection between ownership and structure type.

Regressions (4)-(6) control for metropolitan area fixed effects. The effects get smaller but remain significant. These regressions suggest that part of the effect of ownership subsidies works by pushing people toward metropolitan areas that are more car friendly.

\section{Exhibit 4}

\begin{tabular}{|c|c|c|c|c|c|c|}
\hline & \multicolumn{6}{|c|}{ Dependent Variable: Commuting by Car $(1=y e s, 0=n o)$} \\
\hline & (1) & (2) & (3) & (4) & (5) & (6) \\
\hline Home ownership & $\begin{array}{c}0.109 \\
(1089.34)^{\star *}\end{array}$ & & $\begin{array}{c}0.038 \\
(300.57)^{\star \star}\end{array}$ & $\begin{array}{c}0.079 \\
(787.45)^{\star \star}\end{array}$ & & $\begin{array}{c}0.042 \\
(335.30)^{\star \star}\end{array}$ \\
\hline 1-family house, detached & & $\begin{array}{c}0.127 \\
(646.06)^{\star \star}\end{array}$ & $\begin{array}{c}0.103 \\
(488.68)^{\star \star}\end{array}$ & & $\begin{array}{c}0.092 \\
(471.14)^{\star \star}\end{array}$ & $\begin{array}{c}0.066 \\
(312.27)^{\star \star}\end{array}$ \\
\hline 1-family house, attached & & $\begin{array}{c}0.06 \\
(237.37)^{\star \star}\end{array}$ & $\begin{array}{c}0.043 \\
(166.95)^{\star *}\end{array}$ & & $\begin{array}{c}0.053 \\
(210.46)^{\star *}\end{array}$ & $\begin{array}{c}0.035 \\
(134.73)^{\star \star}\end{array}$ \\
\hline 2-family building & & $\begin{array}{c}0.021 \\
(76.92)^{\star *}\end{array}$ & $\begin{array}{c}0.017 \\
(62.13)^{\star *}\end{array}$ & & $\begin{array}{c}0.03 \\
(114.35)^{\star *}\end{array}$ & $\begin{array}{c}0.026 \\
(98.78)^{\star \star}\end{array}$ \\
\hline 3- to 4-family building & & & & & & \\
\hline 5-family or larger building & & $\begin{array}{c}-0.024 \\
(113.84)^{\star *}\end{array}$ & $\begin{array}{c}-0.022 \\
(107.41)^{\star \star}\end{array}$ & & $\begin{array}{c}-0.006 \\
(28.77)^{\star \star}\end{array}$ & $\begin{array}{c}-0.004 \\
(21.14)^{\star *}\end{array}$ \\
\hline MSA Controls Used? & No & No & No & Yes & Yes & Yes \\
\hline Constant & $\begin{array}{c}-1.283 \\
(2697.55)^{\star \star}\end{array}$ & $\begin{array}{c}-1.302 \\
(2620.97)^{\star \star}\end{array}$ & $\begin{array}{c}-1.280 \\
(2549.65)^{\star \star}\end{array}$ & $\begin{array}{c}-1.299 \\
(1078.62)^{\star \star}\end{array}$ & $\begin{array}{c}-1.330 \\
(1096.65)^{\star \star}\end{array}$ & $\begin{array}{c}-1.307 \\
(1076.19)^{\star \star}\end{array}$ \\
\hline Observations & $9.41 e+07$ & $9.41 e+07$ & $9.41 e+07$ & $9.41 e+07$ & $9.41 e+07$ & $9.41 e+07$ \\
\hline R-squared & 0.30 & 0.31 & 0.31 & 0.32 & 0.32 & 0.33 \\
\hline
\end{tabular}

MSA = metropolitan statistical area.

Notes: (1) Absolute value of t statistics in parentheses. (2) ** Significant at 1\%. (3) All regressions control for age and income. Source: Ruggles, Steven, J., Trent Alexander, Katie Genadek, Ronald Goeken, Matthew B. Schroeder, and Matthew Sobek. 2010. Integrated Public Use Microdata Series: Version 5.0 [Machine-readable database]. Minneapolis: University of Minnesota 
Driving longer distances and owning a car are also associated with negative externalities associated with traffic. Living in multifamily dwellings in the urban center ensures far less traffic on highways than does driving into the city center from single-family detached dwellings in the suburbs. By subsidizing a move away from larger multifamily units, the home mortgage interest deduction is implicitly adding to America's traffic problem. In this case, subsidizing low-density living is more likely to be a problem within metropolitan areas than across metropolitan areas, because traffic problems are actually less severe in lower density areas.

Subsidizing single-family dwellings also means increasing energy use, because such dwellings are typically larger and use more energy for both home heating and electricity. Per-unit electricity usage is 36 percent higher in single-family detached dwellings than in apartment buildings with five or more units. Natural gas usage is 45 percent higher. ${ }^{5}$ These results do not control for household size or income, but Glaeser and Kahn (2010) did control for these factors and still found significantly lower household energy use for households that live in urban cores.

The policy implication of this energy finding is that living in single-family detached dwellings creates an externality because of energy use and traffic congestion. The best intervention would be to tax energy use and traffic at its social cost. As long as America lacks such taxes, however, subsidizing single-family detached dwellings only increases driving and home energy use. This increase in driving and home energy use provides a reason to rethink our subsidizing of homeownership, which implicitly subsidizes single-family detached dwellings.

\section{The Economic Consequences of Promoting Single-Family Dwellings}

Another potential cost of subsidizing single-family detached housing is that it will distort location decisions across metropolitan areas in a way that reduces aggregate productivity. Across metropolitan areas, density is strongly correlated with incomes and productivity (Ciccone and Hall, 1996). Glaeser and Gottlieb (2008) found that, on average, as density doubles, productivity rises by 3 percent, holding individual characteristics constant. I found the same effect for population size, when both population and density are included in the regression. A long and distinguished urban literature focuses on this fact and attempts to understand why productivity rises in dense agglomerations.

Across metropolitan areas, there is a -.32 correlation between the share of the housing stock that is single-family detached and median income in the 2000 Census. An even larger - .42 correlation occurs between the share of the population that lives in single-family detached homes and the logarithm of per-capita gross metropolitan product. Similarly, a positive correlation exists between both of these economic productivity variables and the share of the population that rents in the metropolitan area. Because subsidizing homeownership creates incentives to move to metropolitan areas that specialize in single-family detached homes, these incentives may be pushing Americans out of the denser, more productive metropolitan areas.

The income tax creates an externality associated with earning more. When workers earn higher wages because they live in a more productive area, others experience some of the benefit from their

${ }^{5}$ http://www.eia.doe.gov/emeu/recs/recs2005/c\&e/spaceheating/pdf/allTablesl-13.pdf. 
earnings because of the higher taxes that those workers pay. At the city level, this externality means that too few people move into high-earnings areas, as emphasized by Albouy (2009). Subsidizing homeownership only makes this worse.

\section{The Social Consequences of Subsidizing Single-Unit Dwellings}

Social issues may be associated with incentivizing Americans to leave denser environments. If proximity breeds empathy, as Luttmer's work (2001) shows that support for redistribution rises among people who live near poorer people of the same race, then distance may reduce that empathy. Because poorer people tend to live disproportionately in cities (Glaeser, Kahn, and Rappaport, 2008), bribing wealthier people to leave higher density apartments is increasing the physical, and possibly also the social, distance between rich and poor.

In general, we believe that homeownership leads to a greater investment in social capital, as suggested by DiPasquale and Glaeser (1999). But Glaeser and Gottlieb (2006) also found that certain social activities, such as writing to a newspaper and attending a place of worship, are higher in dense areas. By encouraging people to leave dense areas, the home mortgage interest deduction is implicitly discouraging those social investments. As suggested by the model, the pure ownership effect of the deduction runs up against the fact that the costs of social interaction may be higher at longer distances, and that should make us more cautious about thinking that the deduction always promotes better citizenship.

One does not need to accept these speculative arguments to conclude that the home mortgage interest deduction needs to be rethought, in part, because of its connection with structure type. No one has convincingly shown that apartment living creates negative externalities, and it is certainly clear that in the area of energy use, living in large single-family homes leads to more carbon emissions. In the absence of compelling evidence for negative externalities, the natural stance of the economist is presumably to favor a level playing field between apartments and homes. The current policy is decidedly not a level playing field.

If encouraging larger homes also encourages larger lots, then this situation also creates negativenot positive-externalities. Of course, as I discuss in the next section, local policies that limit the development of high-density housing similarly lead to more driving and more carbon usage.

\section{Rental Housing, Structure Type, and Local Barriers to Building}

One unfortunate side effect of reducing the home mortgage interest deduction could be an increase in rental rates, at least in the short run. If the demand for rental units rises, then prices will rise. One natural means of counteracting that force is to increase the supply of rental housing by loosening the barriers to building multiunit housing.

The federal pro-homeownership policies are not the only public policies that stack the deck against higher density rental housing. At the local level, communities have long made it difficult to build, with land use restrictions that are often specifically targeted at multiunit dwellings. Although very small governmental units frequently enact these restrictions, they can have national implications. A reasonable case can be made that the extraordinary post-1990 growth of Atlanta, Dallas, Houston, and Phoenix, and the far more limited expansion of the regions around New York, Boston, and San 
Francisco, owes much to the differences in land use regulations between these two sets of places (Glaeser and Tobio, 2008). Restricting high-density dwelling can lead to higher carbon emissions and movement away from more productive areas, which will have an adverse effect on national income. These restricting factors make local land use policy a national concern.

In this section, I review two types of land use policies and their impact on multiunit dwellings and prices. First, I consider suburban land use restrictions. I then consider land use policies within the large cities that are the natural places for tall, multiunit structures. I then discuss the pattern of land use restrictions across space.

\section{Land Use Restrictions in the Suburbs}

A long and distinguished literature exists on land use restrictions in suburban areas. For example, Katz and Rosen (1987) examined growth controls in the San Francisco region and found less development and higher prices accompanied these limits on building. Much of this literature has focused on a narrow region of the country, because institutional structures differ from state to state and rules often change at very low levels of geography. No one section of the country can be considered typical, and, at best, a particular region can be illustrative of only a particular style of land use policy.

With those caveats, I will briefly describe the fairly intensive investigation of land use rules in greater Boston undertaken by Amy Dain, Jenny Schuetz, Bryce Ward, and me, which is found in Glaeser, Schuetz, and Ward (2006) and Schuetz (2008). This work gives a sense of the extent to which some areas have stacked the deck against multifamily dwelling. Both papers focused on 187 cities and towns that were within 50 miles of Boston. Boston itself was not included because the city's planning process-like that of many larger cities-is quite sui generis. We used a combination of census data, Banker \& Tradesman sales price data, zoning data from the MassGIS system, and the results of an extensive questionnaire filled out by representatives of each of the 187 cities and towns.

Although a great maze of regulations affects various forms of development, two rules are particularly relevant for the development of multifamily dwellings: (1) much land is zoned to allow only single-family detached dwellings, and (2) In areas that do allow multifamily dwellings, restrictions on minimum lot size per unit make multifamily dwellings more difficult to build.

For example, Schuetz (2008) found that 127 out of 186 areas have literally no land where by-right development (that is, no special permits or procedures are needed) of multifamily dwellings could occur. Another 47 have less than 10 percent of their area where by-right multifamily housing could occur. Sixty communities have no land area that allows multifamily dwellings even with a special permit, while an additional 65 allow multifamily construction by special permit on less than 10 percent of their land area. These data are fairly remarkable, because the survey includes places such as Brookline and Cambridge, which are quite close to Boston and quite urban in character.

Moreover, those places that do allow multifamily dwellings often have fairly large minimum lot sizes associated with the development. For example, out of the 59 communities that allowed some multifamily building by right, 26 required a minimum lot size of 20,000 square feet. Of the 126 communities that allowed multifamily dwelling somewhere, by special permit, 79 required a lot size of more than 20,000 square feet and 28 required a lot size of more than 80,000 square feet. In other words, these places allow multifamily dwellings but only if each unit is associated with about 2 acres of land. 
We have every reason to think that these rules are effective at limiting the production of multifamily dwellings. Schuetz (2008) found a strong, positive effect of the number of by-right lots on the amount of multifamily permitting. Glaeser, Schuetz, and Ward (2006) found that more multifamily permitting occurs as the average lot size for multifamily units decline. These results control for distance to Boston and historic density levels, which suggests that these rules are not merely reflecting the low state of demand for multifamily dwellings in outlying areas. The rules preventing the construction of multifamily units are, in fact, limiting the supply of new multifamily units. ${ }^{6}$

The increase in land use controls may explain the significant decline in permitting within the Boston region and, in particular, multifamily permitting. In the 1960s, 172,459 permits were issued in the Boston area, but, even though prices rose dramatically, only 84,105 permits were issued in the 1990s. In the 1960s, more than one-half of all permits were for multifamily construction. In the 1990s, more than 80 percent of permits were for single-family housing. Some of this change surely reflects the decline in publicly subsidized multiunit projects, but it is hard not to suspect that limitations on multifamily building played some role in the massive change.

The work on greater Boston illustrates a region that has made it quite difficult to build multiunit dwellings. Because multiunit dwellings are disproportionately rental, this difficulty for people to build multifamily units means that the supply of rental units is likely to have also been restricted by these rules. In some cases, these communities are sufficiently far from the metropolitan area's core so that it would be surprising to find much multiunit building, but these rules also apply to many inner ring suburbs, where multiunit dwellings are quite plausible. Moreover, some of these outlying areas might also have developed higher density neighborhoods if zoning had allowed it, perhaps built around a major employer or a rail stop.

\section{Land Use Restrictions in the City}

Restrictions on multiunit construction tend to be far more severe in suburbs than in central cities, but the barriers to building in the cities may be more important because they affect the area that is the most natural place to build multifamily units. Suburban building is difficult, but urban building is far more complicated. Few green fields for new construction exist in older cities, and most large buildings get produced through a complicated, ad hoc procedure. Glaeser, Gyourko, and Saks (2005) used condominium sales prices and construction costs to estimate that perhaps one-half of the cost of units in New York City can be seen as the cost of restrictions on building up, but their approach has little ability to determine which specific rules and regulations are most important in driving down construction and driving up costs.

It is certainly clear that permitting activity has decreased in many older cities and that, in many places, the construction of rental units has particularly slowed. Glaeser, Gyourko, and Saks (2005) documented the decline in new construction in New York City between the 1960s and the 1990s, which is all the more remarkable because prices rose dramatically over this time period. In the

\footnotetext{
$\overline{{ }^{6} \text { Schuetz (2008) found }}$ little clear connection, however, between these policies and rental costs, perhaps because neighboring areas are close substitutes for one another, or because her work was not able to control for many unit characteristics.
} 
country as a whole, the number of new rental units being produced declined dramatically from the 1980s, when 358,000 new multiunit rental properties were produced during an average year, ${ }^{7}$ to the last decade, when 179,000 new multiunit rental properties were produced annually. ${ }^{8}$

Cities constrain the development of new buildings in many ways. The permitting process can take years, zoning codes often restrict building heights, and older areas can be landmarked in ways that restrict new development. It is often easy to see the increasing scope of regulations that restrict redevelopment of older areas, even though it may be hard to ascertain the effect of any particular policy. For example, Glaeser (2010) described the growth of historic preservation districts in Manhattan, and interest continues in expanding the size of Manhattan's historic districts, which would make even more areas of the city essentially off limits to new, larger scale development.

During the past 45 years, large areas of New York City have come to be part of historic districts. The estimate in Glaeser (2010) is that nearly 16 percent of Manhattan south of 96th street (excluding parks) is in a historic district. Moreover, those districts occupy much of the city's best real estate, such as the land abutting Central Park. More than one-half of the land in historic districts is made up of three very large districts: Greenwich Village (added in 1969), the Upper East Side District (added in 1981), and the Upper West Side District (added in 1991). Since the Mayor Dinkins era, relatively limited new districting activity has occurred in Manhattan.

The Landmarks Preservation Commission, which reviews all proposals to change exteriors within historic districts, is charged with maintaining the traditional character of these areas. It should be no surprise, therefore, that they have not typically approved large-scale demolitions that would create taller buildings. For example, the Landmarks Commission denied permission to the developer Aby Rosen, who proposed erecting a Norman Foster-designed tower on 980 Madison Avenue that would have kept the façade of the Sotheby-Park-Bernet building. Glaeser (2010) reported evidence suggesting that significantly fewer tall buildings have been constructed, and less growth in the number of housing units has occurred, in historic districts.

Glaeser (2010) also reported the demographic changes that happened in historic districts relative to other areas in Manhattan south of 96th street. Over time, the demographics of the areas that became historic districts became relatively richer, better educated, and more White. The prices in these areas also rose faster than in other comparable areas. Perhaps because they are not building new rental housing, these areas are becoming ever more elite. Jane Jacobs postulated that preserving older housing would make cities more diverse, but historic districts appear to be having the opposite effect.

I do not mean to suggest that preservation districts are the most important means by which cities restrict the development of highrise units. They surely are not, at least in the United States. They simply illustrate one of the many ways in which new residential construction is limited in older cities. By restricting new construction, cities are not providing as much new housing as they could, which, in turn, increases congestion by pushing development out toward the urban fringe and increases pollution by pushing people into larger suburban homes.

\footnotetext{
${ }^{7}$ http://www.census.gov/const/startsusintenta.pdf.

${ }^{8}$ http://www.census.gov/const/www/quarterly_starts_completions.pdf.
} 


\section{Patterns Across Metropolitan Areas}

Although much of the research on land use restrictions has focused on particular policies within metropolitan areas, a smaller literature looks across areas. Some papers (for example, Glaeser and Gyourko, 2002) have drawn inferences based on prices, construction levels, and land density alone. That work certainly seems to suggest that important supply differences exist across space that cannot be accounted for by land availability, and that the value of land is itself far too low to explain differences in home prices across metropolitan areas. Other papers (for example, Gyourko, Saiz, and Summers, 2007; Saiz, 2010) have used the Wharton Land Use Restrictiveness Index to try to explain the differences in home prices across metropolitan statistical areas. ${ }^{9}$

The Wharton Index was based on a questionnaire sent out to land use professionals throughout the country. Gyourko, Saiz, and Summers (2007) then averaged the responses to relevant questions to form a place-specific index. The place-specific indices were then averaged to form a metropolitan-areawide index of land use regulation. Typically, the index is normalized to have a mean of 0 and a standard deviation of 1 across places. Several cross-metropolitan area facts have been established using the index.

One fact is that a robust positive correlation exists between the Wharton Index and price across metropolitan areas (Gyourko, 2009). For example, a one-standard-deviation increase in the index is associated with a 23-percent increase in housing prices. Naturally, a causal interpretation of this relationship is difficult because the Wharton Index is associated with many other factors, such as the education level of the metropolitan area. Saiz (2010) also showed that the index is positively correlated with topographic limits to supply, such as hilliness and coastline. Saiz (2010) also demonstrated that demand shocks have had more of a positive effect on price in areas with more land use regulation.

Other work has looked at the effect of land use control indices on population and local economic growth. For example, Nandwa and Ogura (2010) found a negative correlation among several land use indices and area growth. The Wharton Index correlation with growth is negative but not significantly so, perhaps because the index is correlated with hard-to-measure variables that are positively correlated with demand.

Glaeser and Kahn (2010) looked at the relationship between the Wharton Index and carbon emissions for new households across metropolitan areas. I found that the more restrictive areas have less energy use, primarily because of their temperate climates. Disproportionately restricting the growth of more environmentally friendly areas, such as coastal California, presumably shifts new development toward less environmentally friendly, but more pro-development areas, such as Houston.

\footnotetext{
${ }^{9}$ Malpezzi (1996) played an important role in developing the index.
} 


\section{Conclusion: Toward a New Housing Policy}

What would an ideal national housing policy look like? A purist might hold that because the citizenship benefits of homeownership have not been conclusively proven, it makes sense to have no pro-homeownership bias whatsoever. Perhaps the tax system should move away from an earnings tax toward a consumption tax, which would favor all forms of investment, but the purist's position would avoid any pro-homeownership bias whatsoever.

A less extreme position is to accept that some benefits from homeownership do come from greater investment in social capital. In this case, it becomes reasonable to subsidize homeownership in some way. But even with a belief in subsidizing homeownership, the current system still seems poorly targeted, highly regressive, and excessively engineered to encourage borrowing money and buying big homes.

One feasible path to reform would be to gradually lower the upper limit on the home mortgage interest deduction by $\$ 100,000$ per year over the next 7 years. Currently, the mortgage interest deduction is capped at $\$ 1$ million. President George W. Bush's tax reform panel suggested that this should be cut substantially. To avoid creating too much change in the housing market too quickly, the cap could be cut by $\$ 100,000$ per year for the next 7 years. This gradualist approach would be unlikely to significantly roil markets and it would have little effect on the vast majority of Americans whose mortgages are below $\$ 300,000$.

By lowering the cap on the deduction, the extreme incentives to borrow money to buy big houses would be reduced. The incentives to buy houses that cost more than $\$ 300,000$ would be substantially reduced. Some of the worst distortions associated with the home mortgage interest deduction would be eliminated. The artificial incentive to borrow would be capped at $\$ 300,000$, and the artificial incentive to buy would drop off at somewhat more than that amount. A lower cap on the home mortgage interest deduction would achieve some of the benefits of eliminating the deduction altogether with a much less drastic policy shift.

After America achieved a lower tax deduction, it would be possible to envision proposing an alternative situation in which all homeowners-or all homeowners below a certain income threshold-receive a flat homeowner's tax credit that is independent of the size of the home and the size of the mortgage. This annual tax credit would go to any homeowner who occupied his or her home. The flat tax credit would appeal to people with smaller mortgages and it would reduce the benefit to borrow and buy big. For example, assume that a tax credit of $\$ 2,000$ per year was available to all homeowners. This credit would be appealing to people whose marginal tax interest rate obligations were less than $\$ 66,000$ per year and who had a marginal tax rate of less than 30 percent. If the prevailing interest rate were 6.6 percent, every homeowner who had a mortgage of less than $\$ 100,000$ would be eligible for the tax credit. The tax credit could be made market specific so that higher tax credits were available in more expensive markets.

Even this flat tax policy would have the unfortunate side effect of encouraging people to leave cities that are dense with apartment buildings. If we wanted to encourage homeownership but limit the density-reducing effect of homeownership policies, it would be possible to slightly offset 
the ownership tax credit with a density tax credit. For example, the ownership credit would be higher in places where density levels were higher. Renters could also receive a tax credit for living in high-density areas.

Alternatively, the tax credit could be tied to the area's cost of living instead of the density level. Giving a positive tax credit in places that are more expensive to live would reduce the tax incentive to leave those high-cost areas. Moreover, because housing is more expensive near the city center, this tax credit would reduce the incentive to flee the core.

Having a homeowner's tax credit and accurately taxing the costs of driving and low-density living may be the best solutions. If individuals paid for the full social cost of their energy use (and traffic congestion), then we would not need to create further distortions that would push people toward dense living environments. Better energy pricing would also induce more efficient energy usage along other margins.

Although these suggested proposals for policy change may be one economist's ideal, they will most likely not make any political headway. These proposals are too far from the status quo to have a chance of being implemented. Because I do not think it makes sense to let the perfect be the enemy of the good, I will suggest a policy path that is also difficult but less obviously impossible than a wholesale eradication of one of Washington's most popular policies.

This suggested path would move the United States toward a system in which homeownership were handled with a flat tax credit that creates no incentives to borrow or buy big. Moreover, after we adopted a flat credit, we could then reasonably ask whether homeownership actually delivers social capital that is worth $\$ 2,000$ per year. That debate could have the positive effect of pushing legislators toward adopting policies that are more soundly grounded on real evidence about the magnitude of the externalities of homeownership.

Although reducing the cap on the home mortgage interest deduction would create a fairer, less biased system, it would do little to make life better for renters except allow them to pay a slightly smaller share of the federal tax burden. Indeed, reducing the incentive to own may increase the demand for rental units and push rental costs up, at least in the short run. Ideally, we would pass legislation to ease the rental burden to offset this effect.

In the previous section on rental housing, structure type, and local barriers to building, I argued that limiting new construction artificially boosts housing prices. Unfortunately, it is quite difficult for the federal government to meaningfully influence local land use decisions. One strategy, borrowed from the U.S. Department of Education's "Race to the Top," is to offer a reward to localities that make meaningful changes that will increase the supply of multifamily rental housing units. If a pot of aid, which could be used for local housing-related infrastructure, were tied to changes in the permitting environment, then this incentive could both serve as a demonstration project and provide a meaningful push toward new development.

One reasonable way to proceed would be to allocate a pot of money that would then be allocated after 48 months based on new units produced relative to historic trends and changes in the land use and permitting procedures. The allocations could be paid for with the increased tax revenues coming from changes to the home mortgage interest deduction or with the low-income housing 
tax credit. Indeed, one way of structuring the program would just be to allocate LIHTC funds to localities based on past performance in the construction of multifamily units and changes in the permitting process.

Another approach would be for the U.S. Department of Housing and Urban Development (HUD) to undertake lawsuits against communities that excessively restrict new development. Recently, HUD successfully undertook a case in Westchester, New York, that led to some regulatory reform. The court system invariably involves a fair amount of randomness and unpredictability, but as evidenced by the Mount Laurel system, ${ }^{10}$ it can achieve powerful results. Mount Laurel itself offers an attractive model in which exclusive communities essentially pay a price for their restrictiveness, which then promotes more affordable housing elsewhere-this serves as a tax on NIMBYism. ${ }^{11}$

\section{Final Words}

For too long, America has had privileged homeownership without fully internalizing the consequences of its programs. This policy's specific structure has had adverse consequences: we subsidize borrowing and thereby encourage people to over-leverage themselves to bet on the vicissitudes of the housing market. One adverse consequence, however, would occur in any pro-homeownership policy. Because ownership and structure are so tightly linked, promoting homeownership means promoting single-family detached homes at the expense of multiunit dwellings.

This subsidy pushes people away from cities and toward sprawling suburbs. This push has adverse consequences for the environment and the economy. We need to rethink our pro-homeownership stand and, at the very least, eliminate some of the most extreme features of the home mortgage interest tax deduction. Slowly lowering the cap on the interest deduction would be quite reasonable. At the same time, we should also consider policy decisions that discourage the tendency of many localities to ardently oppose new development of multiunit structures.

\section{Appendix: Model}

In this appendix, I examine the investment decisions of renters, owners, and landlords. I first focus on an investment that improves the physical condition of the house, which could be cleaning the gutters or fighting mold. I assume that this investment is noncontractible so that the renter cannot be paid for it by the owner or vice-versa. If the renter undertakes the maintenance action, there is a cost of $\mathrm{T}$ units of time and the cost of this in foregone after-tax earnings is (1-t)WT, where $\mathrm{W}$ is the tenant's wage and $\mathrm{t}$ is the tax rate, plus $\mathrm{M}$, any cash costs.

A tenant will undertake this improvement investment if and only if the cost (1-t)WT is less than the consumption benefit of the investment during the resident's time in the house, denoted B, minus any increase in the rental payments charged by the landlord, which we denote $\Delta \mathrm{R}$. The

\footnotetext{
${ }^{10}$ In a 1975 court case, the Burlington County, New Jersey National Association for the Advancement of Colored People sued the Mount Laurel Township because the township's zoning ordinances restricted lower income people from finding affordable housing.

${ }^{11}$ The term NIMBYism is derived from the phrase, "Not in my back yard."
} 
house is more attractive as a result of the maintenance, and the landlord certainly has an incentive to charge more. All costs, benefits, prices, and rents are assumed to be time zero discounted real values for algebraic simplicity.

A homeowner will undertake this investment if and only if the cost of the investment, again (1-t) WT $+M$, is greater than the benefit of the investment during the resident's time in the house, which I assume is still B, plus any increase in the final sales price of the house, which we denote $\triangle P$. As such, owner-occupiers will engage in maintenance while renters will not, as long as

$$
\Delta P+B>(1-t) W T+M>B-\Delta R .
$$

In some cases, a landlord may be willing to make the investment. We assume that the cost to the landlord is $\delta W T+M$, in before-tax dollars. The term $\delta$ is meant to capture the possibility that the landlord has access to either more efficient or less expensive labor. I also assume that there is a potential legal penalty, denoted $\mathrm{K}$, for failing to engage in the maintenance, which reflects regulations that may apply to home maintenance. This legal penalty is presumably an expected value because maintenance will often be hard to establish in a court of law. Because the landlord will typically be taxed on all earnings and be able to deduct expenses, the landlord will undertake the action if and only if

$$
\Delta P+\Delta R+K>\delta W T+M
$$

In this case, the maintenance is more likely to be performed if the rent impact, the price impact, or the legal penalty is high.

I assume that the unit experience $\mathrm{N}$ possible opportunities for maintenance. These opportunities have identical costs but differ in their benefits $B$, which equal $\hat{B}+\mu$, where $\mu$ is characterized by a density function $f(\mu)$. I assume that $\Delta P=\theta_{p} B$, and $\Delta R=\theta_{R} B$, where $\theta_{R} \leq 1$, and I calculate benefits by adding together the benefits received by the landlord and tenant in after-tax dollars. I further assume that, if the benefits of a maintenance action are positive for the landlord, then the landlord will take the maintenance action. The demand for homeownership will rise if the maintenancerelated benefits of owning the home are larger relative to the benefits of renting it. With these assumptions, the following proposition follows.

\section{Proposition 1:}

(a) If $\frac{(1-t) W T+M}{1-\theta_{R}}<\frac{\delta W T+M-K}{\theta_{P}+\theta_{R}}$, then renters will engage in some maintenance themselves, and, in this case, owner-occupied units always have more maintenance than rental units.

(b) If $\frac{(1-t) W T+M}{1-\theta_{R}}>\frac{\delta W T+M-K}{\theta_{P}+\theta_{R}}$, then in rental units, the tenants will perform no maintenance and more maintenance will occur in rental units than in owner-occupied units if $\mathrm{K}$ is greater than some value $\mathrm{K}^{*}$, which is decreasing with $\theta_{R}$, increasing with $\mathrm{t}$ and $\delta$, falling with $\mathrm{W}$ and $\mathrm{T}$ if and only if $\delta>\frac{\theta_{R}+\theta_{P}}{1+\theta_{P}}(1-t)$, and increasing with $\mathrm{M}$ if and only if $1>\theta_{R}$.

(c) If $\mathrm{K}=0$, then more maintenance will occur in owner-occupied units if and only if $\delta<(1-t)$ $\frac{\left(\theta_{R}+\theta_{P}\right)}{\left(1+\theta_{P}\right)}-\frac{\left(1-\theta_{R}\right)}{\left(1+\theta_{P}\right)} \frac{M}{W T}$. 


\section{Proof of Proposition 1:}

If $\frac{\delta W T+M-K}{\theta_{P}+\theta_{R}}<\frac{(1-t) W T+M}{1-\theta_{R}}$, then some projects will be done by tenants, not by landlords. In that case, owner-occupation will always lead to more maintenance, because the condition for tenants engaging in maintenance is always more stringent than the condition for owner-occupiers engaging in maintenance.

If $\frac{\delta W T+M-K}{\theta_{P}+\theta_{R}}<\frac{(1-t) W T+M}{1-\theta_{R}}$, then any value of $\mathrm{B}$ that induces the tenant to engage in maintenance will also induce the landlord to engage in maintenance, and, by assumption, this means that only the landlord will invest in maintaining the house. Comparing the landlord's condition with the owner's condition, it follows that the landlord will invest when $\mu>\frac{\delta W T+M-K}{\theta_{P}+\theta_{R}}-\hat{B}$ and the owner-occupier will invest if $\mu>\frac{(1-t) W T+M}{1+\theta_{P}}-\hat{B}$. The landlord will invest more often if and only if $K>K *=\frac{\left(1-\theta_{R}\right) M+W T\left(\delta-(1-t) \theta_{R}+(\delta+t-1) \theta_{P}\right)}{1+\theta_{P}}$. The value of $K^{*}$ is clearly increasing with $M$ if and only if $1-\theta_{R}$, decreasing with $\theta_{R}$, increasing with $\mathrm{t}$ and $\delta$, and decreasing with $\mathrm{W}$ and $\mathrm{T}$ if and only if $\delta>\frac{\theta_{R}+\theta_{P}}{1+\theta_{P}}(1-t)$.

If $\mathrm{K}=0$, then more maintenance in rental units will occur if and only if $\delta<(1-t) \frac{\left(\theta_{R}+\theta_{P}\right)}{\left(1+\theta_{P}\right)}-\frac{\left(1-\theta_{R}\right)}{\left(1+\theta_{P}\right)} \frac{M}{W T}$. I expect tenants to pay rents equal to a constant $\mathrm{Q}$ plus the benefits that they would receive in the house from owning. The constant is meant to reflect flexibility or other benefits associated with renting. I assume that the landlord and owner-occupier discount the eventual sales price at an equal rate. To focus on the maintenance-related forces driving homeownership, I ignore local taxes and financing differences by assuming that everyone is paying up front. I assume that $\frac{(1-t) W T+M}{1-\theta_{R}}>\frac{\delta W T+M}{\theta_{P}+\theta_{R}}>\frac{(1-t) W T+M}{1+\theta_{P}}$ so that landlords perform maintenance on rental apartments and they do less maintenance than owners. In this case, it follows that-

\section{Proposition 2:}

There exists a value of $\mathrm{Q}$, denoted $\mathrm{Q}^{*}$, at which owner-occupiers and landlords are willing to pay the same amount for a unit. Landlords are willing to pay more if $Q>Q^{*}$ and tenants are willing to pay more if $\mathrm{Q}<\mathrm{Q}^{*}$. The value of $\mathrm{Q}^{*}$ is rising with $\mathrm{t}$ and $\delta$, falling with $\theta_{R}$, and rising with $\hat{B}$ if $f\left(\frac{\delta W T+M}{\theta_{P}+\theta_{R}}-\hat{B}\right)$ is uniform and if $\delta>1-t$. The value of $Q^{*}$ is rising with $M$ as long as $f\left(\frac{\delta W T+M}{\theta_{P}+\theta_{R}}-\hat{B}\right)$ and $\delta$ are not too much greater than 1 -t.

\section{Proof of Proposition 2:}

I let $B_{0}$ reflect the baseline benefits from owning the home and $P_{0}$ refers to the sales price with no maintenance. Recall that all prices and benefits are net present values as of the time of purchase.

The expected total after-tax benefits to the homeownership net maintenance costs equal-

$$
B_{0}+P_{0}+N \int_{\mu=\frac{(1-t) W T+M}{1+\theta_{P}}-\hat{B}}^{\infty}\left((\hat{B}+\mu)\left(1+\theta_{P}\right)-(1-t) W T-M\right) f(\mu) d \mu .
$$


If the unit is rented then the expected sales price plus rental revenues net of maintenance costs will equal-

$$
Q+B_{0}+P_{0}+N \int_{\mu=\frac{\delta W T+M}{\theta_{P}+\theta_{R}}-\hat{B}}^{\infty}\left((\hat{B}+\mu)\left(1+\theta_{P}\right)-\delta W T-M\right) f(\mu) d \mu .
$$

if $\frac{\delta W T+M}{\theta_{P}+\theta_{R}}>\frac{(1-t) W T+M}{1-\theta_{R}}$.

The value of $\mathrm{Q}$ at which landlords and homebuyers are willing to pay the same amount for a home equals N times $\int_{\mu=\frac{(1-t) W T+M}{1+\theta_{P}}-\widehat{B}}^{\infty}\left((\hat{B}+\mu)\left(1+\theta_{P}\right)-(1-t) W T-M\right) f(\mu) d \mu-\int_{\mu=\frac{\delta W T+M}{\theta_{P}+\theta_{R}}-\widehat{B}}^{\infty}\left((\widehat{B}+\mu)\left(1+\theta_{P}\right)-\right.$ $\delta W T-M) f(\mu) d \mu$. The derivative of this with respect to $\delta$ is $W T\left(1-F\left(\frac{\delta W T+M}{\theta_{P}+\theta_{R}}-\hat{B}\right)\right)+\frac{W T}{\theta_{P}+\theta_{R}} f\left(\frac{\delta W T+M}{\theta_{P}+\theta_{R}}-\hat{B}\right)$ $\left(\frac{\delta W T+M}{\theta_{P}+\theta_{R}}\left(1+\theta_{P}\right)-\delta W T-M\right)>0$. The derivative of this with respect to $t$ is $W T\left(1-F\left(\frac{(1-t) W T+M}{1+\theta_{P}}-\hat{B}\right)\right)>0$. The derivative of this with respect to $\theta_{R}$ is clearly negative.

The derivative of this with respect to $\hat{B}$ is $\left(1+\theta_{p}\right)\left(F\left(\frac{\delta W T+M}{\theta_{P}+\theta_{R}}-\hat{B}\right)-F\left(\frac{(1-t) W T+M}{1+\theta_{P}}-\hat{B}\right)\right)+\frac{1-\theta_{R}}{\left(\theta_{P}+\theta_{R}\right)}$ $\bar{I}^{2}(\delta W T+M) f\left(\frac{\delta W T+M}{\theta_{P}+\theta_{R}}-\hat{E}\right.$. If $\mathrm{f}($. $)$ is uniform, then this is positive if and only if $\delta>1-t$. The derivative of this with respect to $\mathrm{M}$ is $-\left(F\left(\frac{\delta W T+M}{\theta_{P}+\theta_{R}}-\hat{B}\right)-F\left(\frac{(1-t) W T+M}{1+\theta_{P}}-\hat{B}\right)\right)+\frac{1-\theta_{R}}{\left(\theta_{P}+\theta_{R}\right)^{2}}(\delta W T+M)$ $f\left(\frac{\delta W T+M}{\theta_{P}+\theta_{R}}-\hat{B}\right)$. If $\mathrm{f}($.$) is uniform, then this is positive if and only if (1-t-\delta) W T+\frac{\left(1-\theta_{R}\right)^{2}}{\left(\theta_{P}+\theta_{R}\right)^{2}}(\delta W T+M)>0$, which always holds true if $\delta$ is not too much larger than 1-t.

Proposition 2 gives us a natural measure of the demand for homeownership, the level of Q, which is the premium placed on ownership that is needed to induce landlords and owner-occupiers to pay the same amount for the same unit. Higher values of Q mean that homeownership will be relatively more common, because landlords will buy only when there is a higher premium for the liquidity premium of renting.

We focus instead on building-specific interventions, such as improving the roof, fixing the electrical system, or improving public spaces. Although it is possible for individual residents to undertake such interventions on their own, it is more natural that they coordinate in some fashion with a condominium or cooperative association. I assume that all costs are now paid for with a fee $\mathrm{M}$ and the $\mathrm{Q}=0$.

We assume that decisionmaking costs "d" units per person, so if there are U units in the association, the total decisionmaking cost is $\mathrm{dU}$. This decisionmaking cost can reflect the time lost in attending meetings and debating in a condominium association. Moreover, I assume that everyone must pay this decisionmaking case. Alternatively, one could assume that the association delegates authority to a third-party manager, but then I would have to include the cost and possible waste of that manager whose incentives are unlikely to be perfectly aligned with the owners' incentives.

If there is a single landlord, that landlord pays $d$ in decisionmaking cost. Landlords will engage in repair if and only if $\left(\theta_{p}+\theta_{R}\right) B>M$. A condominium association will engage in repair if and only if $\left(\theta_{p}+1\right) B>M$, so repairs will always be more frequent with the condominium association. This implies the following proposition. 


\section{Proposition 3:}

If $\mathrm{d}$ is large, then I denoted building size as $\mathrm{U}^{*}$, at which owner-occupiers and landlords receive the same benefits. For building sizes above $\mathrm{U}^{*}$, owner-occupancy is less attractive than renting and, for sizes below $\mathrm{U}^{*}$, owner-occupancy is more attractive. The value of $\mathrm{U}^{*}$ is falling with $\mathrm{d}$ and $\theta_{R}$ and if $f(\mu)$ is uniform, $\mathrm{U}^{*}$ is independent of $\hat{B}$ and rising with $\mathrm{M}$.

\section{Proof of Proposition 3:}

Then the expected benefits from owning will equal

$$
B_{0}+P_{0}-d+N \int_{\mu=\frac{M}{1+\theta_{P}}-\hat{B}}^{\infty}\left((\hat{B}+\mu)\left(1+\theta_{P}\right)-M\right) f(\mu) d \mu .
$$

The expected benefit per unit of being a landlord is

$$
B_{0}+P_{0}-d / U+N \int_{\mu=\frac{M}{\theta_{R}+\theta_{P}}-\hat{B}}^{\infty}\left((\widehat{B}+\mu)\left(1+\theta_{P}\right)-M\right) f(\mu) d \mu .
$$

The benefits will be equal if $\frac{(U-1) d}{U}=N \int_{\mu=\frac{M}{\theta_{R}+\theta_{P}}-\hat{B}}^{\frac{M}{\theta_{P}}-\hat{B}}\left(\left(\hat{B}+\mu_{A v e}\right)\left(1+\theta_{P}\right)-M\right) f(\mu) d \mu$. The right-hand side of the expression is always positive. The left-hand side equals zero if $\mathrm{U}=1$ is increasing with $\mathrm{U}$ and goes to $\mathrm{d}$ if $\mathrm{U}$ goes to infinity. As long as $d>N \int_{\mu=\frac{M}{1+\theta_{P}}-\hat{B}}^{\frac{M}{\theta_{R}+\theta_{P}}-\hat{B}}\left(\left(\widehat{B}+\mu_{A v e}\right)\left(1+\theta_{P}\right)-M\right) f(\mu) d \mu$, then there exists a value of $U$, denoted $U^{*}$, at which the two values are equal. The value of $U^{*}$ is falling with $\mathrm{d}$ and rising with anything that causes $N \int_{\mu=\frac{M}{1+\theta_{P}}-\widehat{B}}^{\frac{M}{\theta^{+}+\theta_{P}}-\widehat{B}}\left(\left(\widehat{B}+\mu_{\text {Ave }}\right)\left(1+\theta_{P}\right)-M\right) f(\mu) d \mu$ and falling with anything that causes that expression to fall. As a result, $\mathrm{U}^{*}$ is falling with $\theta_{R}$. The derivative of $N \int_{\mu=\frac{M}{1+\theta_{P}}-\hat{B}}^{\frac{M}{\theta_{R}+\theta_{P}}-\hat{B}}\left(\left(\hat{B}+\mu_{A v e}\right)\left(1+\theta_{P}\right)-M\right) f(\mu) d \mu$ with respect to $\hat{B}$ is $N$ times $\left(1+\theta_{P}\right)\left(F\left(\frac{M}{\theta_{R}+\theta_{P}}-\hat{B}\right)-F\left(\frac{M}{1+\theta_{P}}-\hat{B}\right)\right)-\left(\frac{1-\theta_{R}}{\theta_{R}+\theta_{P}}\right) M f\left(\frac{M}{\theta_{R}+\theta_{P}}-\hat{B}\right)$. If $\mathrm{f}($.$) is uniform, then this equals$ zero. The derivative with respect to M equals $-\left(F\left(\frac{M}{\theta_{R}+\theta_{P}}-\hat{B}\right)-F\left(\frac{M}{1+\theta_{P}}-\hat{B}\right)\right)+\frac{1-\theta_{R}}{\left(\theta_{R}+\theta_{P}\right)^{2}} M f\left(\frac{M}{\theta_{R}+\theta_{P}}-\hat{B}\right)$. If $\mathrm{f}($.$) is uniform, then this is always positive.$

Finally, I turn to social capital investments, which I define as investments that affect the quality of the neighborhood but not the neighborhood's structure. One way to view these investments is that they require time but not money and only the residents can make them. These investments may also create externalities. In general, equation (1) continues to hold and I should expect to see more investments from homeowners than from renters, both because homeowners internalize the benefits of future price increases and because they do not lose from increases in rents. These increased investments provide one justification for the correlations between homeownership and social capital found by DiPasquale and Glaeser (1999) and others.

Another question is whether structure or individual characteristics will connect with these investments. For example, it is natural to assume that both benefits and the costs of investment are a function of the size of the building. It might be easier to connect with others in large, dense structures, in which case T might be declining with U. Alternatively, the benefits of social capital might be lower or higher in denser areas. Social capital may be less valuable if people are more 
connected to the streets in shorter buildings or it may be more valuable if there is more need for community associations to make blocks safer. I define the benefits of social capital as $\int_{\mu=\underline{\mu}}^{\infty}((\hat{B}+\mu)$ $\left.\left(1+\theta_{P}\right)-(1-t) W T\right) f(\mu) d \mu$, where $\mu$ is the relevant cutoff level.

\section{Proposition 4:}

(a) Holding building structure constant, investment in social capital is always higher in owneroccupied than in rental properties, and if $f(\mu)$ is uniform, then the increased investment associated with owner-occupancy is rising with building size (U) if and only if the time costs of investing in social capital decline with building size $\left(0>\frac{\partial T}{\partial U}\right)$.

(b) If renters occupy larger buildings, then homeowners may invest less in social capital if the time costs of investing in social capital decline sufficiently with building size (that is, if $\frac{\partial T}{\partial U}$ is sufficiently negative).

\section{Proof of Proposition 4:}

The benefits of extra investment in social capital equals $N$ times $\int_{\mu=\frac{(1-t) W T}{1+\theta_{P}}-\hat{B}}^{\frac{(1-t) W T}{1-\theta_{R}}-\hat{B}}\left((\hat{B}+\mu)\left(1+\theta_{P}\right)-\right.$ $(1-t) W T) f(\mu) d \mu$, which is always positive. The derivative of this with respect to $\mathrm{U}$ equals $\left(F\left(\frac{(1-t) W T}{1-\theta_{R}}-\hat{B}\right)-F\left(\frac{(1-t) W T}{1+\theta_{P}}-\hat{B}-\hat{B}\right)\right)\left(\left(1+\theta_{P}\right) \frac{\partial \hat{B}}{\partial U}-(1-t) W \frac{\partial T}{\partial U}\right)+f\left(\frac{(1-t) W T}{1+\theta_{P}}-\hat{B}-\hat{B}\right)$ $\frac{\left(\theta_{R}+\theta_{P}\right)(1-t) W T}{1-\theta_{R}}\left(\frac{\partial T}{\partial U} \frac{(1-t) W}{1-\theta_{R}}-\frac{\partial \hat{B}}{\partial U}\right)$. If $\mathrm{f}($.$) is uniform, then this becomes \frac{\left(1+\theta_{P}\right)^{2}-\left(1-\theta_{R}\right)^{2}}{\left(1+\theta_{P}\right)\left(1-\theta_{R}\right)^{2}}((1-t) W)^{2} T \frac{\partial T}{\partial U}$ times the density of $\mu$, which is positive if and only if $\frac{\partial T}{\partial U}$ is positive.

Let $U_{R}$ define the building size for renters and $U_{P}$ define the building size for owners. These then imply different values of $\hat{B}$ and $T$, for renters and owners, which I denote as $T_{R}$ and $\hat{B}_{R}$ for renters and $T_{P}$ and $\hat{B}_{P}$ for owners. Owners will invest more than renters if and only if $\frac{(1-t) W T_{R}}{1-\theta_{R}}-\hat{B}_{R}>\frac{(1-t) W T_{P}}{1+\theta_{P}}-\hat{B}_{P}$ or $\frac{T_{R}}{1-\theta_{R}}-\frac{T_{P}}{1+\theta_{P}}>\frac{\hat{B}_{R}-\hat{B}_{P}}{(1-t) W}$. This condition can plainly fail to hold if $T_{P}$ is sufficiently high relative to $T_{R}$.

\section{Acknowledgments}

The author acknowledges the Taubman Center for State and Local Government for supporting this work. Kristina Tobio provided superb research assistance.

\section{Author}

Edward L. Glaeser is the Director of the Taubman Center for State and Local Government and the Rappaport Institute for Greater Boston, and he is the Fred and Eleanor Glimp Professor of Economics at Harvard University and a faculty research fellow at the National Bureau of Economic Research. 


\section{References}

Albouy, David. 2009 (August). "The Unequal Geographic Burden of Federal Taxation," Journal of Political Economy 117 (4): 635-667.

Ciccone, Antonio, and Robert E. Hall. 1996. "Productivity and the Density of Economic Activity," American Economic Review 86 (1): 54-70.

Coulson, N. Edward, and Herman Li. 2010. "Measuring the External Benefits of Homeownership." Paper presented at the 46th Annual AREUEA Conference, Denver, Colorado.

DiPasquale, Denise, and Edward L. Glaeser. 1999 (March). "Incentives and Social Capital: Are Homeowners Better Citizens?" Journal of Urban Economics 45 (2): 354-384.

Frankena, Mark. 1975. "Alternative Models of Rent Control," Urban Studies 12 (3): 303-308.

Glaeser, Edward L. 2010 (Spring). "Preservation Follies," City Journal 20 (2): 62-67.

Glaeser, Edward L., and Joshua D. Gottlieb. 2008. "The Economics of Place-Making Policies," Brookings Papers on Economic Activity: 155-239.

2006. "Urban Resurgence and the Consumer City," Urban Studies 43 (8): 1275-1299.

Glaeser, Edward L., and Joseph Gyourko. 2008. Rethinking Federal Housing Policy. Washington, DC: The AEI Press.

2002 (Fall). "Zoning's Steep Price," Regulation 25 (3): 24-30.

Glaeser, Edward L., Joseph Gyourko, and Raven Saks. 2005. "Why Is Manhattan So Expensive? Regulation and the Rise in Housing Prices," The Journal of Law and Economics 48 (2): 331-369.

Glaeser, Edward L., and Matthew E. Kahn. 2010 (May). "The Greenness of Cities: Carbon Dioxide Emissions and Urban Development," Journal of Urban Economics 67 (3): 404-418.

Glaeser, Edward L., Matthew E. Kahn, and Jordon Rappaport. 2008. "Why Do the Poor Live in Cities? The Role of Public Transportation," Journal of Urban Economics 63 (1): 1-24.

Glaeser, Edward L., Jenny Schuetz, and Bryce Ward. 2006. Regulation and the Rise of Housing Prices in Greater Boston. Cambridge, MA: Harvard University, Rappaport Institute for Greater Boston; Boston, MA: Pioneer Institute for Public Policy Research.

Glaeser, Edward L., and Jesse M. Shapiro. 2003. "The Benefits of the Home Mortgage Interest Deduction." NBER chapters in Tax Policy and the Economy, Vol. 17, edited by James M. Poterba. Cambridge, MA: National Bureau of Economic Research: 37-82.

Glaeser, Edward L., and Kristina Tobio. 2008. "The Rise of the Sunbelt," Southern Economic Journal 74 (3): 610-643.

Green, Richard K., and Michelle J. White. 1997. "Measuring the Benefits of Homeowning: Effects on Children," Journal of Urban Economics 41 (3): 441-461. 
Grossman, Sanford J., and Oliver D. Hart. 1986 (August). "The Costs and Benefits of Ownership: A Theory of Vertical and Lateral Integration," Journal of Political Economy 94 (4): 691-719.

Gyourko, Joseph. 2009. "Housing Supply," Annual Review of Economics 1: 295-318.

Gyourko, Joseph E., Albert Saiz, and Anita A. Summers. 2007. A New Measure of the Local Regulatory Environment for Housing Markets: The Wharton Residential Land Use Regulatory Index. Working paper no. 558. University of Pennsylvania: Wharton Real Estate Center.

Henderson, J. Vernon, and Yannis M. Ioannides. 1989. "Dynamic Aspects of Consumer Decisions in Housing Markets," Journal of Urban Economics 26: 212-230.

Katz, Lawrence, and Kenneth T. Rosen. 1987. "The Interjurisdictional Effects of Growth Controls on Housing Prices," Journal of Law and Economics 30 (1): 149-160.

Klein, Benjamin. 2006. "The Economic Lessons of Fisher Body-General Motors." University of California, Los Angeles mimeograph.

Klein, Benjamin, Robert G. Crawford, and Armen A. Alchian. 1978 (October). "Vertical Integration, Appropriable Rents, and the Competitive Contracting Process," Journal of Law and Economics 21 (2): 297-326.

Luttmer, Erzo F.P. 2001. "Group Loyalty and the Taste for Redistribution," Journal of Political Economy 109 (3): 500-528.

Malpezzi, Stephen. 1996. "Housing Prices, Externalities, and Regulation in U.S. Metropolitan Areas," Journal of Housing Research 7 (2): 209-241.

Nandwa, Boaz, and Laudo M. Ogura. 2010 (April). "Do Urban Growth Controls Slow Down Regional Economic Growth?" Available at Social Science Research Network: http://ssrn.com/ abstract $=1583646$.

Poterba, James. 1984. "Tax Subsidies to Owner-Occupied Housing: An Asset-Market Approach," Quarterly Journal of Economics 99 (4): 729-752.

Poterba, James, and Todd Sinai. 2008. "Tax Expenditures for Owner-Occupied Housing: Deductions for Property Taxes and Mortgage Interest and the Exclusion of Imputed Rental Income," American Economic Review 98 (2): 84-89.

Saiz, Albert. 2010 (August). "The Geographic Determinants of Housing Supply," Quarterly Journal of Economics 125 (3): 1253-1296.

Schuetz, Jenny. 2008. "Guarding the Town Walls: Mechanisms and Motives for Restricting Multifamily Housing in Massachusetts," Real Estate Economics 36 (3): 555-586.

Shilling, James D., C.F. Sirmans, and Jonathan F. Dombrow. 1991 (December). "Measuring Depreciation in Single-Family Rental and Owner-Occupied Housing," Journal of Housing Economics 1 (4): 368-383. 